Portland State University

PDXScholar

Spring 2003

\title{
Falling into History: The Imagined Wests of Kim Stanley Robinson in the "Three Californias" and Mars Trilogies
}

Carl Abbott

Portland State University, d3ca@pdx.edu

Follow this and additional works at: https://pdxscholar.library.pdx.edu/usp_fac

Part of the Urban Studies and Planning Commons

Let us know how access to this document benefits you.

Citation Details

Abbott, C. Falling into History: The Imagined Wests of Kim Stanley Robinson in the "Three Californias" and Mars Trilogies. The Western Historical Quarterly, Vol. 34, No. 1 (Spring, 2003), pp. 27-47.

This Article is brought to you for free and open access. It has been accepted for inclusion in Urban Studies and Planning Faculty Publications and Presentations by an authorized administrator of PDXScholar. Please contact us if we can make this document more accessible: pdxscholar@pdx.edu. 


\title{
FALLING INTO HISTORY: \\ The IMAGINED Wests of Kim Stanley RoBinson IN THE "Three CALIFORNias" and MARS TRILOGIES
}

\author{
CARl AbBotT
}

Califormia science fiction uriter Kim Stanley Robinson has imagined the future of Southern California in three novels published 1984-1990, and the settlement of Mars in another trilogy published 1993-1996. In framing these narratives he worked in explicitly historical terms and incorporated themes and issues that characterize the "new western history" of the 1980s and 1990s, thus providing evidence of the resonance of that new historiography.

\section{$\boldsymbol{R}_{\text {ED MARs II KM STANLEr RoBnson's highly- }}$}

praised science fiction novel published in 1993. ${ }^{1}$ Its pivotal section carries the title "Falling into History." More than two decades have passed since permanent human settlers arrived on the red planet in 2027, and the growing Martian communities have become too complex to be guided by simple earth-made plans or single individuals. The section centers on John Boone, an explorer-hero ("the first man on Mars") and charismatic co-leader of the first one hundred settlers. As he spends three years wandering and visiting scattered settlements, he finds that Martian society is outgrowing his capacity to comprehend and direct.

CARL ABBotT is professor of Urban Studies and Planning at Portland State University.

NOTE: Page numbers to the Mars trilogy refer to the Bantam Spectra paperback edition. The books in this trilogy are Red Mars (New York, 1993), Green Mars (New York, 1995), and Blue Mars (New York, 1997). The books in the "Three Californias" trilogy, in sequential order, are The Wild Shore, The Gold Coast, and Pacific Edge. References to The Wild Shore (1984; reprint New York, 1995) and Pacific Edge (1990; reprint New York, 1995) are to the Orb paperback editions.

References to The Gold Coast (New York, 1988) indicate the St. Martin's Press version. Kim Stanley Robinson is the author of both series.

${ }^{1}$ Red Mars won the annual Nebula Award from Science Fiction and Fantasy Writers of America.. Green Mars won the Hugo Award from science fiction fans.

Western Historical Quarterly 34 (Spring 2003): 27-47. Copyright (C) 2003, Western History Association. 
He had been on the road for years now ... cutting ribbons at the opening of one thing or another-a town, a well, a weather station, a mine, a mohole-and always talking, talking in public speeches or private conversations, talking to strangers, old friends, new acquaintances ... and all in an attempt to inspire the people to figure out a way to forget history, to build a functioning society. To create a scientific system designed for Mars, designed to their specifications, fair and just and rational and all those good things. To point the way to a new Mars! And yet after every year that passed, it seemed less likely ... events were out of control, and more than that, out of anyone's control. ${ }^{2}$

Robinson is a novelist who takes history seriously. The fall into history is the transition from the carefully controlled circumstances of a single contingent of firstcomers to the intractability of multiple groups, peoples, values, and agendas. It is the collapse of the open-ended possibilities of a new place into the constrained situations of historicity - the concatenation of habits, hopes, and vested interests that characterize any society. In the words of critic Robert Markley, Robinson imagines a situation in which utopian schemes are inevitably "undone by the distance between the idealized operations of a frictionless system and the wear and tear of embodied, historical experience."

Robinson himself is a Californian, raised in Orange County in the 1950s and 1960s and now living in Davis. One of the most popular and honored science fiction writers of the last two decades, his reputation is based on two trilogies that hold mirrors to multiple historical experiences, prominently including that of the American West. The books that describe "Three Californias"-The Wild Shore, The Gold Coast, Pacific Edge-are explicitly regional, imagining alternative futures for Orange County over the twenty-first century. Red Mars, Green Mars, and Blue Mars constitute a single densely written novel of the settlement of the red planet over two centuries that transposes many of the problems of the American West to a new setting ("a triple decker in the old style," says the author). ${ }^{4}$ Robinson is thus a distinctively western writer whose books are imagined discussions of the very stuff of western history, the inhabitation of "empty" places and their transformation into unexpected sorts of communities. $\mathrm{He}$ himself has commented: "I think of myself as a Californian writer more than I do a science fiction writer, and would be happy to be grouped with the California writers. To be grounded in that way, even regionalized, would be a very good way of giving

\footnotetext{
${ }^{2}$ Robinson, Red Mars, 283.
}

${ }^{3}$ Robert Markley, "Falling into Theory: Simulation, Terraformation, and Eco-Economics in Kim Stanley Robinson's Martian Trilogy," MFS Modern Fiction Studies 43 (Fall 1997): 775.

${ }^{4}$ David Seed, "The Mars Trilogy: An Interview," Foundation: The Review of Science Fiction 68 (Autumn 1996): 76. 
some physicality or heft to the inclination of science fiction to be otherworldly by being set in the future." 5

It is not surprising that a California/western writer may also be a science fiction writer. Americans have long projected political and cultural hopes on the West in forms that range from geopolitical boosterism to communitarian experiments. And we have been particularly eager to burden California with often contradictory roles as arcadia, utopia, and featured player in the collapse of civilization. ${ }^{6}$ Science fiction is a natural extension of such western discourse, reinscribing the hopes and fears that shaped stories of the nineteenth- and twentieth-century West onto settings that stretch even more broadly across space and more deeply into time. Indeed, for many writers of speculative fiction, the western experience of the United States has served as a template for fictional futures. The result, at times, is a seamless connection of centuriesa common set of stories that link the historical past to the imagined future. ${ }^{?}$

Americans have long found it easy to apply the capacious frontier metaphor to realms beyond the stratosphere. Most television viewers know of the Starship Enterprise, which boldly voyages through "space: the final frontier" in endlessly recycled episodes of Star Trek. Closer to home, Disneyland juxtaposed the rocketships of Tomorrowland and the coonskin caps of Frontierland. ${ }^{8}$ Star Trek creator Gene Roddenberry drew on a rich heritage of space adventure stories in crafting his television series (originally conceptualized as "wagon train to the stars"). "Space operas" as western horse operas with ray guns were a staple of pulp magazine fiction in the 1930s and 1940s. The Buck Rogers and Flash Gordon movies of the same era even inspired a Gene Autry serial called The Phantom Empire, in which Gene alternates between singing cowboy duties and captivity by ray-gun wielding Thunder Riders from the 100,000. year-old subterranean "scientific city" of Murania. The new Magazine of Fantasy and Science Fiction and Galaxy magazine, both started in the 1950s, still appeared on cheap

${ }^{5}$ Kim Stanley Robinson, letter to author, 14 August 2001.

${ }^{6}$ William A. McClung, Landscapes of Desire: Anglo Mythologies of Los Angeles (Berkeley, 2000) and Mike Davis, City of Quartz: Excavating the Future in Los Angeles (New York, 1990).

${ }^{7}$ Insightful studies of the connections between science fiction and the American uses of standard literary genres and sensibilities such as the romance and the gothic novel include David Ketterer, New Worlds for Old: The Apocalyptic Imagination, Science Fiction, and American Literature (Garden City, NY, 1974); David Mogen, Scott P. Sanders, and Joanne B. Karpinski, eds., Frontier Gothic: Terror and Wonder at the Frontier in American Literature (Rutherford, NJ, 1993); Gary Westfahl, Space and Beyond: The Frontier Theme in Science Fiction (Westport, CT, 2000); David Mogen, Wilderness Visions: The Western Theme in Science Fiction Literature, ed. Daryl F. Mallett, $2^{\mathrm{d}}$ ed. (San Bernadino, CA, 1993); Gary K. Wolfe, "Frontiers in Space," in The Frontier Experience and the American Dream, ed. David Mogen, Mark Busby, and Paul Bryant (College Station, TX, 1989), 248- $\rightarrow$ Beverly J. Stoeltje, "Making the Frontier Myth: Folklore Process in a Modern Nation," Western Folklore 46 (October 1987): 235-53.

${ }^{8}$ Michael Steiner, "Frontierland as Tomorrowland: Walt Disney and the Architectural Packaging of the Mythic West," Montana The Magazine of Western History 48 (Spring 1998): 2-17. 
paper but were conscious efforts to elevate the genre, with Galaxy editor H. L. Gold advertising that there would be no westerns disguised as science fiction in his pages.

More recently, the idea of a "high frontier" for American ingenuity and enterprise has been a political project. The rhetoric of John F. Kennedy connected the New Frontier to the goal of a manned mission to the moon, and former astronaut John Glenn later invoked the image of space as "the modern frontier for national adventure." In the 1970s, Gerard K. O'Neill gave the metaphor an engineering twist with his detailed proposal for a high frontier of inhabited artificial satellites. The U. S. National Commission on Space in 1986 described the settlement of North America as a prologue to the space frontier. Lobbying organizations and publishers continue to keep alive the idea that the necessary next frontier will be space exploration, translating an old maxim into upward the course of empire takes its way. ${ }^{10}$

Robinson himself challenges these well-worn conventions by emphasizing community rather than heroism, civic life rather than adventure, and environmental management rather than economic opportunity. His trilogies address both the scientific-industrial politics of the high frontier and the literary formulas that underlie this political project. By taking seriously the possibilities of a cooperative commonwealth, both in Pacific Edge and in the Mars books, he questions the inevitability of capitalist economies. His attention to the dynamics and problems of social inclusion and exclusion undercut the easy nationalism of the earthly and unearthly frontiers. His attention to settlement and society contravene the dynamic of perpetual change that is embedded in the frontier myth.

I have two specific goals in this discussion: (1) to explore the ways in which Robinson as a western American author understands history and pivots his narratives on issues of historical interpretation, and (2) to examine how he incorporates into his fictions some of the familiar tropes and interpretations of the American western experience. The larger, implicit subject is the incorporation of western American history into popular culture, viewed through the ways that Robinson uses and transforms issues central to historical understanding and interpretation of the American West and other European settlement frontiers. In particular, we can gain new insights into the meaning of the West in American minds by examining how Robinson has dealt with such issues as the future of urbanization, the possibilities of intentional communities and of economic cooperation, governance on a settlement frontier, the responsibilities of leadership in a democracy, the clash between raw nature and human use of the

\footnotetext{
${ }^{9}$ John Glenn quoted in Ray A. Williamson, "Outer Space as Frontier: Lessons for Today," Western Folklore 46 (October 1987): 259.

${ }^{10}$ Gerard K. O'Neill, The High Frontier: Human Colonies in Space (New York, 1976); U. S. National Commission on Space, Pioneering the Space Frontier: The Report of the National Commission on Space (New York, 1986); Harry L. Shipman, Humans in Space: $21^{\text {st }}$ Century Frontiers (New York, 1989).
} 
landscape, and the political tensions between colony and imperium. There is, I believe, much in Robinson's projections of future historical change that incorporates or echoes the critical thinking about environment, conquest, inequality, and community associated with the "new western history" with its emphasis on the multiplicity and complexity of events and the contingency of narratives. ${ }^{11}$ Reading his work may make us more sensitive participants in this historical conversation and give us greater understanding of how increasingly complex ideas about the American West are entering the world of popular culture.

Kim Stanley Robinson explicitly defines science fiction as historical in character-as articulated narratives that can be seen as anchored at their origins in "real" times and circumstances. "In every science fiction narrative," he writes, "there is an explicit or implicit fictional history that connects the period depicted to our present moment." That is to say, science fiction is narrative that starts with or assumes the historical present and writes it forward. In a different interview, he makes a parallel point in calling science fiction "the history that we cannot know." Readers can assume that a plausible sequence of events might lead from their present to the events in the story and can observe how the writer varies the assumptions behind those events. Science fiction is thus a set of thought experiments, as Martian society is itself characterized during one of the political debates in Green Mars. ${ }^{12}$

Robinson's definition differentiates true science fiction from many of the books and videos that sit on the science fiction shelves in libraries, bookstores, and Blockbuster video outlets. Science fiction is not cheerful Harry Potter fantasies nor dark vampire melodramas; it is not extra-terrestrial monster-slaying tales, sword-and-castlein-a-different-universe romances, nor space operas set in some other galaxy a long time ago. Instead, Robinson aligns himself with hard science fiction writers who have crafted explicit future histories such as Robert Heinlein, David Brin, and Ken MacLeod

11 The "new western history" is a catchall term for a disparate set of scholars whose work emphasizes the costs as well as benefits of the European occupation of western North America and the continuities between the nineteenth and twentieth centuries in the American West. It also involves concern for multiple ideas about the meaning of the western experience and careful attention to voices that were under represented in early versions of regional history, such as women, wage workers, immigrants, and people of color. Representative publications include Patricia Nelson Limerick, Legacy of Conquest: The Unbroken Past of the American West (New York, 1987); Richard White, "It's Your Misfortune and None of My Own": A History of the American West (Norman, OK, 1991); Patricia Nelson Limerick, Charles E. Rankin, and Clyde A. Milner, II, eds., Trails: Toward a New Western History (Lawrence, KS, 1991); Clyde A. Milner II, Carol O'Connor, and Martha Sandweiss, eds., The Oxford History of the American West (New York, 1994).

${ }^{12}$ Kim Stanley Robinson, "Notes for an Essay on Cecelia Holland," Foundation: The Review of Science Fiction 40 (Summer 1987): 54; Bud Foote, "A Conversation with Kim Stanley Robinson," Science-Fiction Studies 21 (March 1994): 52; Robinson, Green Mars, 376. 
and with so-called cyberpunk writers like William Gibson and Bruce Stephenson who project the near future of an electronically linked and mediated society. ${ }^{13}$

Robinson argues the virtues of historical fiction as a counterpart of science fiction. In comments on the work of historical novelist Cecelia Holland, he states that historical fiction and science fiction share the challenge of making intelligible the inner workings of alien cultures, and thereby illuminating our own cultural and social values. He also shares Holland's interest in politics-in the ways that people wield power and the ways that the powerless can resist the powerful. It is therefore possible "to write historical fiction for the same reason one writes science fiction: to take advantage of the psychological power of the estrangement effect, which in pulling readers momentarily out of their ordinary world views, gives them the chance to see things anew." ${ }^{14}$

In comments on his own work, Robinson places himself on a map of literary influences anchored by Joseph Conrad's socially-embedded adventures and Thomas Pynchon's ability to ground surreal narratives on the foundations of existing times and places. Several of Pynchon's purportedly mainstream novels-particularly The Crying of Lot 49 and Vineland-deal with oddly off-kilter Californias that start out as places that we can recognize but drift inexorably into places of the imagination. The oppressor state that lurks beneath the sunny California surface in Vineland looks like the dark future that has been explicitly avoided in Pacific Edge. In the course of the Martian narrative, the center of gravity slowly shifts from the challenges faced by individuals to the complexities of bringing change to living societies. This is the same progression that we see in Conrad from the isolated protagonists of Almayer's Folly and Lord Jim to the complex colonial society described in Nostromo and the ambiguities of revolution as analyzed in The Secret Agent. ${ }^{15}$

Robinson is a theoretically sophisticated writer. He earned a master's in English from Boston University and a doctorate from the University of California-San Diego,

${ }^{13}$ This is not to say that Robinson shares Heinlein's Ayn Randish political philosophy or the viewpoints of the cyberpunks, whom he characterizes as an expression of the 1980 s mentality of "caving to capitalism and concentrating on how to get one's own without worrying about the larger picture. ... going with the flow of the world supermarket." Thomas E. Jackson, "Interview with Kim Stanley Robinson," The New York Review of Science Fiction no. 117 (May 1998): 15. Ken MacLeod states that "history is the trade secret of science fiction, and theories of history are its invisible engine" in his introduction to the U. S. edition of The Star Fraction (New York, 2001), 11 .

${ }^{14}$ Robinson, "Notes for an Essay on Cecelia Holland," 60. Robinson's most recent book, The Years of Rice and Salt (New York, 2002), is an alternative future novel set on an earth where 95 percent of Europe's population perished in the Black Death, leaving Asian civilizations to contend for global hegemony.

${ }^{15}$ Thomas Pynchon, The Crying of Lot 49 (Philadelphia, 1966) and Vineland (Boston, 1990); Joseph Conrad, Almayer's Folly: A Story of an Eastern River (New York, 1895), Lord Jim: A Tale (Edinburgh, 1900), Nostromo: A Tale of the Seaboard (New York, 1904), and The Secret Agent: A Simple Tale (New York, 1907). 
where he worked with the influential literary scholar Fredric Jameson, perhaps best known as the critic who deconstructed the Westin Bonaventure Hotel in Los Angeles in "Postmodernism, or the Cultural Logic of Late Capitalism."16 His dissertation examined science fiction writer Philip K. Dick, whose work anticipated the shifting viewpoints of postmodernism and includes the story that Ridley Scott turned into the movie Blade Runner. ${ }^{17}$ As a licensed but non-practicing academic, Robinson is fully aware of the traps in seeing history as sets of analogies, which mislead us as often as they helpalthough the unpacking or deconstruction of historical analogies is central to his Mars fiction. ${ }^{18}$ In Red Mars, for example, John Boone tries to warn unhappy settlers that they are not the exact equivalent of the "hardy pioneer colonists" of 1775 and that changed circumstances make it impossible to reenact the American Revolution. In Blue Mars, the crafters of a new Martian constitution pick carefully among the numerous analogies from the political travail of twentieth-century Earth. ${ }^{19}$

Robinson also turns history-writing and the politics of memory into one of the motifs of his novels. A central character in The Wild Shore is the village storyteller, who manufactures a useable past for the survivors who eke out a livelihood from farming and fishing along the Southern California coast. Still a teenager when the bombs fell, he creates an imaginary career, adds three decades to his life, and spins tall tales into a half-accurate history to inspire the post-disaster generations. Pacific Edge alternates a communitarian present in the year 2065 with excerpts from a diary that touches on the political struggles that led to that particular set of social and economic institutions. The author of the diary is the same individual as the storyteller in the other book, living through a different future.

In the Mars Trilogy, Robinson uses the science fiction gimmick of longevity treatments to maintain the members of the first-hundred settlers through two centuries of Martian history. Their own changing understanding of the present in light of their (and others') reinterpretations of the past becomes one of the themes and driving factors for the second and third volumes. Robinson models the problems and

${ }^{16}$ Fredric Jameson, "Postmodernism, or the Cultural Logic of Late Capitalism," New Left Review no. 146 (July-August 1984): 53-92.

${ }^{17}$ Blade Runner, dir. Ridley Scott (1982). Other of Dick's fictions were the seeds for the films Total Recall, dir. Paul Verhoeven (1990), based on the story "We Can Dream it for You Wholesale," originally published in Fantasy \& Science Fiction (April 1966), and reprinted in The Collected Stories of Philip K. Dick, Vol. 2 (New York, 1995), 35-52; and The Truman Show, dir. Peter Weir (1998), based on Time Out of Joint (Philadelphia, 1959).

${ }^{18}$ See Ernest R. May, "Lessons" of the Past: The Use and Misuse of History in American Foreign Policy (New York, 1973); Richard E. Neustadt and Ernest R. May, Thinking in Time: The Uses of History for Decision Makers (New York, 1986); Peter Stearns, "Forecasting the Future: Historical Analysis and Technological Determinism," The Public Historian 5 (Summer 1983): 31-54;

$\rightarrow$ Otis L. Graham, Jr., "The Uses and Misuses of History: Roles in Policymaking," The Public Historian 5 (Spring 1983): 5-19.

${ }^{19}$ Robinson, Red Mars, 348; Seed, "Mars Trilogy," 79. 
selectivity of historical memory and history writing in the memories of these characters. They habitually search the past for historical comparisons to understand the new Martian politics and society-usually with little success. They worry that they are forgetting the meaning of their own lived past. They repeatedly contemplate the character of historical understanding and stand bemused or infuriated when they find themselves reinterpreted as characters in history books or even in opera. The stories they tell about their own pasts become factors in the shaping of their present and future. ${ }^{20}$

The first trilogy, written in the 1980s, imagines three very different futures for Orange County, California. The Wild Shore describes a village climbing back to tribalism after the neutron bombing of the United States. The historical record is truncated, and the survivors are too busy toiling for food and shelter to sift historical fact from fiction. The Southern California of The Gold Coast is a straight line projection of an overcrowded "condomundo" where alienated young people do designer drugs with eyedroppers, drive automobiles with electronic guidance systems, and toy with terrorism against the transnational corporations that twist their coils around every activity. In Pacific Edge, the alternative is a federation of ecologically sensitive communities organized around the "small is beautiful" precepts of Ernest Schumacher and the principles of social ecology and mutual aid articulated by political philosopher Murray Bookchin. ${ }^{21}$ Americans have used the political process to gradually rein in corporate America and focus self-government at the local level, although each community remains part of a larger world economy.

Social scientists and planners have developed increasing sophistication about the differences between forecasts and scenarios. Forecasts are quantified analogies that may use sophisticated mathematics but that still succeed or fail on the accuracy of their assumptions; the most important question about forecasts is why and how much change is likely to change-that is, what factors are likely to alter present short-term

${ }^{20}$ See Robinson, Green Mars, 540-2, 359; Robinson, Blue Mars, 678, 713. Also see Carol Franko, "The Density of Utopian Destiny in Robinson's Red Mars," Extrapolation: A Journal of Science Fiction 38 (Spring 1997): 56-65; Markley, "Falling into Theory," 788. Robinson's understanding of history is far different from Isaac Asimov's adolescent image of a mathematical calculus of historical forces in the Foundation novels. Sax Russell, the scientific genius behind terraforming, searches for a "science of history" to explain the rise of social conflict but gives up in the face of historical contingency. (See Robinson, Green Mars, 205-6.) Robinson's use is also different from that of science fiction writers who frequently adopt metahistorical cycle-of-civilization models from Gibbon, Spengler, Ibn Khaldun, and other macrohistorians as mechanical devices to structure grand narratives of far futures. Indeed, Robinson has his own fun with such models by introducing the Martian historian Charlotte Dorsa Brevia who in the 2170s publishes a "dense multivolumed analytical metahistory" that explains Martian society as the logical result of millennia of contest between existing and emergent social and economic systems that eventuate, conveniently in the 2170s, in a new democratic age. (See Robinson, Blue Mars, 482-4.) Her work sounds like nothing if not Hegel and Marx writ large.

${ }^{21}$ Shaun Huston, "Murray Bookchin on Mars! The Production of Nature in Kim Stanley Robinson's Mars Trilogy," in Lost in Space: Geographies of Science Fiction, ed. Rob Kitchin and James Kneale (London, 2002), 167-79. 
trends, rates, and structures. ${ }^{22}$ In contrast, scenario builders attempt to consider possible interrelationships of technical, economic, social, cultural, and political factors. Scenario building in one sense is history on fast forward. Focused on the future, it utilizes disparate pieces of information within a broad context to create an understandable narrative. It may produce surprises, stimulating imaginative construction of alternative possibilities. And it welcomes the techniques of narrative to give body and presence to future possibilities; planners increasingly think of their task as "persuasive storytelling" that links the present to a future..$^{23}$

Robinson demonstrates that his Orange County fictions are precisely these sorts of alternative scenarios by building in specific continuities across the books, a characteristic that he reinforces with a reference in Pacific Edge to Lawrence Durrell's Alexandria Quartet of novels that retell the same story from four points of view. Like much historical writing, the stories are grounded on the importance of place-a particular stretch of coast from Point Dana to San Onofre, the ridges and canyons that trail off the Santa Ana Mountains. The protagonist in each is a young man who matures, in part, by attracting and then failing to hold a strong woman. Each book makes it clear from the roster of characters that Orange County in the twenty-first century will be as much Latino as Anglo. The character Tom Barnard appears in each book at the end of a very different but logically derived life. The storyteller of The Wild Shore and the diary keeper of Pacific Edge, he ends his life in The Gold Coast in a nursing home, reminiscing to occasional visitors. And the books share an explicitly historical motif of digging up the past. Each opens with a group of friends wielding shovels-trekking to abandoned San Clemente to loot a grave for imagined treasure in The Wild Shore, digging beneath the street for the fun of discovering relics of the twentieth century in The Gold Coast, cheerfully sharing required community work on a street project in Pacific Edge.

The trilogy is a set of variations on the common trope of "seeing the future in California." An imposing scholarly literature examines the ways in which greater Los Angeles served through the twentieth century as the summary or shorthand for the American future, the place to get a preview of things to come. More than half a century ago, Carey McWilliams argued that California was twenty years ahead of the rest of the nation. Los Angeles, claimed Neil Morgan in 1963, was "the center of gravity" in the westward tilt that was creating the America of tomorrow in the West of today. Postwar critics called Los Angeles "the ultimate city," the "prototype of the supercity,"

${ }^{22}$ Andrew M. Isserman, "Projection, Forecast, and Plan: On the Future of Population Forecasting," Joumal of the American Planning Association 50 (Spring 1984): 208-21.

${ }^{23}$ Larry Hirschhorn, "Scenario Writing: A Developmental Approach," Journal of the American Planning Association 46 (Spring 1980): 172-83; Peter Hall, Great Planning Disasters (Berkeley, 1980); James A. Throgmorton, Planning as Persuasive Storytelling: The Rhetorical Construction of Chicago's Energy Future (Chicago, 1996). 
the "leading city." Richard Elman was a bewildered New Yorker who traveled to Compton, California, in 1967 "with the thought in mind that this was the future." ${ }^{24}$

In recent years, yet another scholarly generation has declared greater Los Angeles as the prototype for the twenty-first century city. A "Los Angeles School" of urban studies now argues, essentially, that we have in the SoCal metropolis a new urban form and dynamic that is postmodern. Its cityscape and spatiality, its economy and social ecology - all are fragmented, flexible, fluid - not so much formless as constantly in reformation. As expressed by Allen J. Scott, Michael Dear, Edward Soja, and others, this is a metropolis that exemplifies not its past but a coming future. And it is a metropolis where Orange County may seem to manifest the newest of the new as a post-suburban exopolis that can only be understood through fragmentary snapshots. ${ }^{25}$

Place-the Orange County setting - thus matters as the key to the trilogy's impact as well as serving as a factor in each narrative. It seems unlikely that a Fort Wayne trilogy or a Preble County, Ohio, trilogy, no matter how carefully done, would attract the same readership. As Robinson has agreed, Orange County's role as an "awful paradigm for the future ... could not be replaced by just any American city or suburb."26 All three of Robinson's futures gain resonance as subtle departures and challenges to the standard dystopian Los Angeles of Blade Runner and the fictional variations on a Los Angeles apocalypse that Mike Davis recently summarized in The Ecology of Fear. ${ }^{27}$ Davis roots his dark vision in City of Quartz in the collapse of hope in his Southern California hometown of Fontana. In contrast, Tom Barnard in Pacific Edge explicitly identifies the California of his childhood in the 1980s as a "pocket utopia."

California when I was a child was a child's paradise, I was healthy, well fed, well clothed, well housed, I went to school and there were libraries with all the world in them and after school I played in orange groves and in Little League and in the band and down at the beach and every day was an adventure, and when I came home my mother and father created

${ }^{24}$ Carey McWilliams, California: The Great Exception (1949; reprint, Westport, CT, 1971); Neil Morgan, Westward Tilt: The American West Today (New York, 1963), 107; Christopher Rand, Los Angeles: The Ultimate City (New York, $191 \rightarrow$ Arthur L. Grey, Jr., "Los Angeles: Urban Prototype," Land Economics 35 (August 1959): 232-42; Werner Hirsch, "Los Angeles: Leading City? A Leading City," in Los Angeles: Viability and Prospects for Metropolitan Leadership, ed. Werner Z. Hirsch (New York, 1971), 237-41; Richard M. Elman, Ill-At-Ease in Compton (New York, 1967), vii.

${ }^{25}$ Allen J. Scott and Edward W. Soja, eds., The City: Los Angeles and Urban Theory at the End of the Twentieth Century (Berkeley, 1996); Michael J. Dear, Greg Hise, and H. Eric Schockman, eds., Rethinking Los Angeles (Thousand Oaks, CA, 1996); Rob Kling, Spencer Olin, and Mark Poster, eds., Postsuburban California: The Transformation of Orange County Since World War II (Berkeley, 1991).

${ }^{26}$ Kim Stanley Robinson, letter to author, 14 August 2001.

${ }^{27}$ Mike Davis, The Ecology of Fear: Los Angeles and the Imagination of Disaster (New York, 1998). 
a home as solid as rock, the world seemed solid! And it comes to this, do you understand me-I grew up in utopia.

But I didn't. Not really. Because while I was growing up in my sunny seaside home much of the world was in misery, hungry, sick ... I had been on an island ...

And if-if! if someday the whole world reaches utopia, then that dream California will become a precursor, and sign of things to come, and my childhood is redeemed. ${ }^{28}$

To get to that dream is to engage in politics, for the challenges and processes of democratic self-government set another theme that cuts across the three books and leads toward the second trilogy. The Wild Shore contrasts local town-meeting democracy and the strong-man government that emerges from the ruins of San Diego. The second and third books contrast unsuccessful and successful ways to undercut the military-industrial complex. Slapdash terrorism in The Gold Coast turns out to be not only ineffective but corrupted by corporate power. Pacific Edge foregrounds the process of representative democracy-lobbying, bargaining, the use and abuse of bureaucratic rules to advance local interests. In the background narrative, improvements have been achieved incrementally, with political mobilization and organizing over multiple decades. In the intense local debate over developing a portion of the town's remaining open space, change again comes by increment through lobbying and votes in the town council. ${ }^{29}$ Taken together, the books are an examination of how history happens as well as what history might mean.

The Mars Trilogy is panoramic in scope and written from multiple points of view. The books follow the development of Martian society from first settlement by a team of 50 Russians and 50 Americans, through debates over environmental change, immigration, the development of multiple cultures, efforts at political independence, two rounds of constitution-making, "international" negotiations, generational conflicts, and changing social values. The structure is a series of long sections that take the viewpoints of key figures from the first hundred or their descendants. Taken together, the three volumes array the points of view of ten characters across thirty-two sections that average about sixty pages each. ${ }^{30}$ The approach is reminiscent of John Dos Passos's USA. Another comparison is a contemporary writer whom Robinson cites

${ }^{28}$ Robinson, Pacific Edge, 300.

${ }^{29}$ Tom Moylan, “'Utopia is when our lives matter': Reading Kim Stanley Robinson's Pacific Edge," Utopian Studies 6, no. 2 (1995): 9.

${ }^{30}$ There are five sections for Nadia Chernyshevsky, the engineer and political leader; five for Ann Clayborne the ecologist and advocate of red Mars; five for Sax Russell, the scientist; five for Nirgal the second generation leader; four for Maya Toitovna, the charismatic and manipulative leader of the Russian contingent; two for Frank Chalmers, the political pragmatist; two for Michael Duval, the psychiatrist; two for Art Randolph, the political facilitator; one for John Boone; and one for Zo Boone of the third generation. 
as an influence: Peter Matthiessen, author of the Florida frontier trilogy Killing Mister Watson, Lost Man's River, and Bone by Bone. ${ }^{31}$

Robinson's vision of this future clearly draws on the history of North America. The narrative is premised on the technological capacity to "terraform" Mars (in effect making pastures of plenty from dry desert lands). In the tasks set for the original one hundred settlers are echoes of Jamestown and Philadelphia, Astoria and New Archangel; in the careful selection of the settlers for skills and temperaments are parallels to the schemes of nineteenth-century utopian socialists. Evolving experiments in political independence and self-government drive the story. Complicating the political history are conflicts between "reds" and "greens," the factions in this case ironically reversed from our current usage-the reds representing those who desire to leave Mars unaltered "wilderness" and the greens those who wish to adapt it to human use.

The titles-Red Mars, Green Mars, Blue Mars-trace the success of terraforming through massive engineering interventions to raise the ambient temperature and atmospheric pressure, to bring water to the surface, and to introduce plants and animals bioengineered from earth originals. There is careful and fascinating detail about the terraforming process—options, choices, setbacks, side effects, accomplishments. The technical dimension is reminiscent of the cetology and whaling lore in Moby Dick, and Robinson himself argues that "there is no intrinsic reason why scientific detail cannot be as interesting as the stage business of a chase scene." 32

By imagining a first-hundred settlers equally divided among Russians and Americans, Robinson can draw on two structuring metaphors from nineteenth- and twentieth-century history. One is the promise and problems of socialist revolution against the power of capital. The second is the possibilities and processes of community-building in new lands. The first is the big, dramatic framework. The second underlies Robinson's projections of the evolution of everyday life on the high frontier. Both metaphors tie the hypothesized history of Mars to repeated falls into historythe failures of Russian socialism and French revolutionary utopianism; the transformation of New England between the 1630s and the 1680s, of Utah from the nineteenth to the twentieth century, or of any new place that wriggles free from the expectations of its founders. ${ }^{33}$

Red Mars, the first volume, pivots on the possibilities and failures of revolution, and it is full of the intertextuality that literary critics enjoy. A key character among the

${ }^{31}$ The three novels in John Dos Passos's USA trilogy are The $42^{\text {nd }}$ Parallel (New York, 1930), 1919 (New York, 1932), and Big Money (New York, 1936); Peter Matthiessen, Killing Mister Watson (New York, 1990), Lost Man's River (New York, 1997), and Bone by Bone (New York, 1999).

${ }^{32}$ Jackson, "Interview with Kim Stanley Robinson," 18.

${ }^{33}$ We can also read "falling into history" as reference to the biblical fall from innocence in Gen. 3-4. Red Mars is structured around the rivalry of American leaders John Boone and Frank Chalmers, in effect the senior and junior brothers. In the flash forward that opens the book, Chalmers arranges Boone's assassination and thereby recommits the sin of Cain. 
first hundred is Arkady Bogdanov, a charismatic revolutionary who preaches independence from Earth and helps to trigger a failed revolution in 2061 (the Martian equivalent of Russia's 1905 revolution). Martians regroup and try again successfully in 2127 with much better organization - think October 1917-when the oppressive regime is under external stress from eco-catastrophe on Earth. Bogdanov the character bears the name of a real Bolshevik leader, Alexandre Bogdanov, author of his own science fiction novel, Red Star, about the establishment of socialism on Mars. Referenced as well is Nikolai Cherneshevsky's feminist utopia of the 1860s, What Is To Be Done? ${ }^{34}$ The phrase is modified for the section on failure of the first revolution in Red Mars (as "What have we done?!") and for the first section on constitution-making in Green Mars; the heroine of the constitutional convention is Nadia Chernyshevsky, another of the first hundred.

History in the Mars narrative is always conditional and mutable. It is made through the articulation of ideas, public debates, power plays, assassination. It is balanced between structure and agency, culture, politics, and economics. It is "whole, nonrepeatable, and contingent." It escapes the power of Bogdanov, Boone, his rival Frank Chalmers, or earth-based corporations to direct and shape. It shows the messiness of human lifethere is always "more history, more trouble, between us and any decent society" Robinson commented in a 1996 interview. ${ }^{35}$

By Green Mars and Blue Mars, the increased complexity and density of cultures and institutions and "history" make action more problematic and complex. The heroes are now the constitution-makers, and by implication the scientists who help to create an inhabitable Mars. No single narrative can now contain the multifarious history. The model of the Russian revolutions drops away, for no simplifying theory works, in favor of Madisonian political compromises. The meat of the process of community formation is engaged conversation, engaged politics. The key events are now the forging of a revolutionary compact after the first failure ("What Is To Be Done" in Green Mars) and the establishment of formal government after a successful breakway from Earth control ("A New Constitution" in Blue Mars). Nadia, the builder of engineering works and constitutions, emerges as the story's new hero. ${ }^{36}$

Robinson's Mars books are written explicitly against two alternative uses of Mars as frontier. One is the reinscription of the North American conquest narrative onto Mars in fantastic fictions that pay no attention to the science of transportation or

\footnotetext{
${ }^{34}$ John Newsinger, "The Martian Trilogy," Monthly Review: An Independent Socialist Magazine 49 (December 1997): 53-5; Alexander Bogdanov, Red Star: The First Bolshevik Utopia ed. Loren R. Graham and Richard Stites, trans. Charles Rougle (Bloomington, IN, 1984); Nikolai Cherneshevsky, What Is To Be Done? trans. Michael R. Katz (Ithaca, NY, 1989).

${ }^{35}$ Seed, "Mars Trilogy," 77; Robinson, Green Mars, 220.

${ }^{36}$ It is interesting to note that Greg Bear's Moving Mars (New York, 1993) also pivots on the politics and politicking of anti-colonial revolution, although it gives greater importance to a technological means for accomplishing the aim of independence.
} 
settlement. Edgar Rice Burroughs kicked off the genre with "Under the Moons of Mars," in which western American John Carter takes refuge in an Arizona cave to escape Apache warriors, only to find himself on "Barsoom" (his name for Mars) facing much the same situation in a landscape that looks quite southwestern. Carter, whom Burroughs seems to have modeled on the protagonist of Owen Wister's The Virginian, continued his Martian adventures in a dozen books over several decades. The John Carter books were the implicit foil for Ray Bradbury's blithely unscientific but very self-conscious inversion of the same story in The Martian Chronicles, with episodes of genocide, labor exploitation, wasted landscapes, and ghost towns. ${ }^{37}$

From the opposite side of the science/humanities divide is a technologically specific literature that bundles hard science and entrepreneurial values to proclaim Mars as the most practical high frontier. Aerospace engineer Robert Zubrin zeroed in on the next planet out in The Case for Mars, invoking the spirit of Frederick Jackson Turner to proclaim that a new Martian frontier would help recapture the soul of America and, in turn, sparking formation of the Mars Society. ${ }^{38}$ Recent science fiction novels that focus exclusively on dramatizing the technology of Mars exploration include planetary scientist Geoffrey A. Landis's Mars Crossing and Zubrin's own First Landing. Both use that simplest of plots: the stranded explorers who must strike out across country with undaunted courage and work as a team to save themselves. Zubrin also puts his understanding of the American past into the mouth of Kevin McGee, the historian who accompanies the mission:

I'm a historian, and I know that a society cannot have progress, or growth, or hope, unless there is an open frontier. That's what made America in its frontier days such a powerful engine of progress for all humanity .... We became the most creative nation in history, because we could see the infinite potential of the human mind .... We don't build new cities any more, and so we've begun to think of ourselves not as builders of our country, but as mere inhabitants. Our frontier has been gone too long, and now our nation is losing its spark. ${ }^{39}$

${ }^{37}$ Edgar Rice Burroughs, "Under the Moons of Mars," originally published in All-Story magazine (1912), and republished as A Princess of Mars (Chicago, 1917); Owen Wister, The Virginian (New York, 1902); Ray Bradbury, The Martian Chronicles (Garden City, NY, 1958); Gregory M. Pfitzer, "The Only Good Alien Is a Dead Alien: Science Fiction and the Metaphysics of Indian-Hating on the High Frontier," Journal of American Culture 18 (Spring 1995): 51-67; Richard Slotkin, 'Uunfighter Nation: The Myth of the Frontier in Twentieth-Century America (New York, 1992); Paul A. Carter, The Creation of Tomorrow: Fifty Years of Magazine Science Fiction (New York, 1977), 60-9.

${ }^{38}$ Robert M. Zubrin and Richard Wagner, The Case for Mars: The Plan to Settle the Red Planet and Why We Must (New York, 1996); Markley, "Falling into Theory," 779.

${ }^{39}$ Robert Zubrin, First Landing (New York, 2001), 240-1; Greg A. Landis, Mars Crossing (New York, 2000). 
Robinson, too, is a historian of sorts, and one who is less likely than Kevin McGee to make most readers of the Western Historical Quarterly cringe. His fiction is suffused with an awareness of the American West as a historically shaped place. Where the Orange County books present possible extensions of western history, the Mars books adapt and utilize the themes and tropes through which Americans have come to understand that history. These themes illustrate and drive the action, and they are themselves challenged or interrogated by the dynamics of the fictions. And, most intriguingly, they are framed in ways that show familiarity with the themes and criticisms that the so-called new western historians were elaborating in the same years that Robinson was writing. These concerns have been summed up by Patricia Limerick with a series of "c" words: conquest, continuity, convergence, and complexity, to which we might add capitalism and community (with nods to William Robbins and Robert Hine). ${ }^{40}$

As the American West has been, the Martian frontier is projected as a place of often rapacious resource development. The theme of conquest, which is central to the new western history, takes the form of the conquest of nature. The first hundred begin with exploration and road building. Subsequent settlers construct high speed transit lines, build dams, and dig mines. They tap geothermal heat, pump out aquifers, and seed bioengineered plants to add weight, heat, and oxygen to the Martian atmosphere. With no building codes and environmental regulations in place, large corporations dig and run, build company towns on the cheap, and play workers of different nationalities against each other. ${ }^{41}$ Like the Mountain West, Mars is an urban frontier of gateway cities and production cities from which miners and eventually agriculturalists spread outward: Sheffield stands in for a port city like San Francisco, Burroughs for an industrial city like Denver, Serenzi Na for a mining town like Butte, Bradbury for small agricultural cities like Grand Junction.

The history of the American West is testimony to the momentum of engineering technology, the easy step from can do to should do. So too is Martian history. The power and nearly inexorable appeal of terraforming technologies is similar to the American impulse to apply more and more technology to capture and deliver western water. In fact (the twentieth century) and in fiction (the twenty-second century), we see the ramp up from smaller to larger projects, the aesthetic attraction of the technical intervention, the promise of better life, the opening of land to settlement and use. Technical papers at a terraforming conference morph easily into grant applications from ambitious scientists. ${ }^{42}$

${ }^{40}$ Patricia Nelson Limerick, Something in the Soil: Legacies and Reckonings in the New West (New York, 2000), 18-21; William Robbins, Colony and Empire: The Capitalist Transformation of the American West (Lawrence, KS, 1994); Robert V. Hine, Community on the American Frontier: Separate But Not Alone (Norman, OK, 1985).

${ }^{41}$ Robinson, Green Mars, 228.

${ }^{42}$ Ibid., 213, 459-61, 475. 
The terraforming project brings out contrasting environmentalisms of preservation and utilization. The ideas of western irrigation utopians like William Smythe echo in the American advocates of use. They find allies among the Russians, who are also development advocates, reflecting their own national history; the experience they bring is that of intensive exploitation of Siberia and Central Asia. We also hear the voices of preservationists who try to understand Mars in its own terms. In a landscape that has never before supported human beings, there is no way to deny that wilderness and other concepts through which we understand the physical settings of human life are socially constructed. ${ }^{43}$ At one point of a debate over the future of the planet that recurs through the entire trilogy, scientist Sax Russell argues that "the beauty of Mars exists in the human mind. Without the human presence it is just a collection of atoms.... It is we who understand it and we who give it meaning." American ecologist Ann Clayborne, who longs for an unchanging Mars, counters that to truly see Mars requires "fitting into it as it is, and worshiping it with our attention." Another character "humanizes" Mars by devising the "aerophany," a "landscape religion, a consciousness of Mars as a physical space suffused with kami, which [is] the spiritual energy or power that rested in the land itself." More concretely, the protagonists later come to understand the irony of protecting the natural setting from resource development by selling its attractions for tourism. ${ }^{44}$

As in the American West, the place itself takes on the role of actor and influence. We hear echoes of western visionaries such as Gary Snyder, whom Robinson lists as a favorite poet. ${ }^{45}$ The Marsscape looks like the California desert, Monument Valley, the Painted Desert. It is "a Utah of the imagination." Characters look like "weatherbeaten sodbuster[s]" and a scientific outpost like "a desiccated café in the Mojave." Settlers reproduce the flora and fauna of a southwestern canyon in a Martian valley that is tented over to hold in atmosphere. ${ }^{46}$

The idea that a frontier is a social safety valve acts as an exogenous force driving the story. Mars functions as a symbolic (even if not practical) release valve for an Earth collapsing from environmental stress. Crowded countries put in their claims for Martian land and resources, and illicit immigrants arrive despite official quotas and limits. Everyone knows that another planet cannot really relieve pressure at home, but home governments are unwilling to give up the fiction. The planet is linked inextricably to the history of Earth, becoming a cauldron where multinational immigration reproduces old ethnic identities and cultures in desperately pure forms.

${ }^{43}$ William Cronon, ed., Uncommon Ground: Toward Reinventing Nature (New York,

1995).

${ }^{44}$ Robinson, Red Mars, 177, 179, 229; Hal K. Rothman, Devil's Bargains: Tourism in the Twentieth Century American West (Lawrence, KS, 1998).

${ }^{45}$ Jackson, "Interview with Kim Stanley Robinson," 15-8.

${ }^{46}$ Robinson, Red Mars, 40, 183, 261, 245; Robinson, Blue Mars, 275; Robinson, Green

Mars, 364, 425. 
Robinson thus incorporates into the narrative the idea of high frontier as safety valve, but he depicts this as a belief that is no more accurate for Mars than it was for western North America. The willingness of national governments on Earth to peddle the myth of a safety valve complicates the politics of environment and independence. Demands from back home constrain decisions on Mars about the pace of terraforming, for "millions on Earth wanted to come to Mars, to the 'new frontier,' where life was an adventure again." As the settlers later move toward a first revolution, Frank Chalmers notes one of their problems: "Did you see that program aired on Eurovid about all the open land on Mars? . . It was like a real estate ad." John Boone uses the imagery of frontier outpost to inspire settlers to common purpose and Arkady Bogdanov uses the rhetoric of a free and open frontier to recruit settlers from the U.S. to his revolutionboth efforts that end in failure. ${ }^{47}$

The result is that the safety valve fails on both demographic realities (the mismatch between tens of thousands of immigrants and billions on the home planet) and on cultural conflict. Arkady Bogdanov's vision of inventing a new Martian culture from scratch crashes against the persistence of cultural differences among immigrants from Switzerland and India, the United States, Arab nations, and many other cultures. So does John Boone's alternative hope of easily blending the best ideas of Earth into a new society. Here is the theme of convergence from the new western history, an exploration of the ways in which a "white" frontier (pioneered in this case by Americans and Russians) is complicated by the arrival of immigrants from very different cultures, just as the presence of Native peoples and the arrival of Latinos, Chinese, Japanese, Filipinos, and many others has complicated the development of an AngloAmerican West. The constitution makers struggle to reconcile respect for cultural peculiarities with universal rights, hoping at best for "a lot of different cultures coexisting"48

Questions of resource use and community come together in the relations between Earth and Mars, metropolis and colony. Central to the action is the clash between local autonomy and the domination of outside capital and corporations, another of the central issues of the new western history. ${ }^{49}$ Beyond the direct tensions of capitalists and workers, Robinson argues that the global and local are interdependent because local opportunities are always embedded within larger structures. Mars cannot exist without a viable Earth. The societies are linked through cultural heritage and information exchange. The web of economic and cultural connections remains too strong to allow isolated purity. As Americans discovered after 1783 and again after 1815, the web of connections that tie new settlements to their places of origins are not easily severed or ignored..$^{50}$

${ }^{47}$ Robinson, Red Mars, 170, 389, 380, 425.

${ }^{48}$ Robinson, Green Mars, 337.

${ }^{49}$ For a discussion of this, see Robbins, Colony and Empire.

${ }^{50}$ Moylan, "'Utopia is when our lives matter," 8, 19; Seed, "Mars Trilogy," 77;

Robinson, Blue Mars, 23. 
To be sure, one temptation in the face of pressure from Earth is to light out for the country in a repetition of a romantic version of western America. Nirgal, the epitome of the first Mars-born generation, reaches for the outback when things get too crowded. ${ }^{51}$ So does the narrative's wildcard, a stowaway on the original voyage who makes the first hundred actually one hundred and one. He takes on the identity and role of the North American trickster Coyote. ("Coyote is out there in the back of the hills, breathing the air already and doing what he wants, the bastard"). ${ }^{52} \mathrm{He}$ travels the backlands organizing for economic separateness and political separation, and he argues passionately against connection to the past, but his influence gradually wanes.

As in the American West, such individualism contrasts and clashes with very specific sectarian versions of community. The empty Marsscape invites secular and religious utopian colonies. In the demimonde beyond corporate control, and between revolutions, are colonies and communities of Sufis, Baptists, Quakers, and Rastafarians. There are followers of Rousseau, adherents of Fourier, and, in another academic joke, acolytes of Foucault. ${ }^{53}$ There are also radical Marsfirst ecoterrorists and mystical Marsworshipers in the self-contained community of Zygote, concealed under the south polar ice. Hiroko Ai, the prophet of aerophany, explains the intention to John Boone:

We have a vision of what life on Mars can be. We could see it wasn't going to go that way. We have been proved right by what has happened since. So we thought we would establish our own life .... We want to try it, to show by experiment how we can live here. Someone has to show what you mean when you talk about a different life, John Boone. Someone has to live the life..$^{54}$

In fact, heroic individualism is replaced not by utopian experiments but by the merits of civic life. Robinson's alternative for Mars is also the great alternative for understanding western America: frontier as community building. The course of the Mars books problematizes end-state utopias. (This is also why the Russian model drops away.) The future must be found in the unruly and morally complex processes of community making, not in intellectualized schemes. We have, I think, a fictionalized version of Stanley Elkins's and Eric McKitrick's meaning for Frederick Jackson Turner's

\footnotetext{
${ }^{51}$ For a time he becomes an isolated homesteader, reenacting another model of the western American experience.

${ }^{52}$ Robinson, Green Mars, 48. Western American mythology is also reproduced in the afterlife of John Boone. His reputation, after his death, becomes legend and conflates with tales of Paul Bunyan on Mars ... who in turn encounters a Martian Big Man a hundred times larger yet than Paul and Babe. Robinson, Red Mars, 386.
}

${ }^{53}$ Markley, "Falling into Theory," 782; Robinson, Green Mars, 230, 326.

${ }^{54}$ Robinson, Red Mars, 374. 
frontier in the challenges of working together and Robert Hine's search for western community in the bonding of people with place..$^{55}$

The pivotal figures of the trilogy remain John and Nadia, the people who talk. The true solution is to build civil society through conversation. Mars at its best, says critic Carol Franko, is "an argumentative and interdependent confederation of diverse communities." ${ }^{" 6}$ Boone seeks utopia through dialog, and the speech in which he sums up his ideas about forging a new Martian society pulls together and packs together thoughts and suggestions that he has picked up in years of conversation. Nadia and her supporters seek stability through negotiation. They work the hallways during political meetings and do the hard work of community organizing. Franko references literary theorist Mikhail Bakhtin and the literary-linguistic idea of "dialogism" in which meaning emerges from the continual interaction among people, their words, their actions, and their unspoken ideals. ${ }^{57}$ In Bakhtin's view, novels establish their worlds by setting multiple voices in interaction, allowing their characters to form new meanings from the play within and between persons and words.

These theoretical statements return us as well to the ideas of Pacific Edge, where utopia is also a "process of making a better world, the name for one path history can take, a dynamic, tumultuous, agonizing process, with no end." 58 This preferred Orange County is a utopia achieved through legislation. Political participation matters, the process is more important than the end state, and victories can be real even if small and sometimes morally ambiguous. In Robinson's view, "utopia has to be rescued as a word, to mean 'working towards a more egalitarian society, a global society." Utopia is "a road of history, something we are working within." 59

Like many contemporary writers in the social sciences and cultural studies, Robinson wants to explore the challenges that face conscious community building

${ }^{55}$ Hine, Community on the American Fron $\rightarrow$ Stanley Elkins and Eric McKitrick, "A Meaning for Turner's Frontier: Part I: Democracy in the Old Northwest," Political Science Quarterly 69 (September 1954): 321-53.

${ }^{56}$ Franko, "The Density of Utopian Destiny in Robinson's Red Mars," 60.

${ }^{57}$ Robinson, Red Mars, 378-81; Franko, "The Density of Utopian Destiny in Robinson's Red Mars," 61. Mikhail Mikhailovich Bakhtin was a Russian literary critic and philosopher (1895-1975) who worked during the Soviet era. His work first came to the attention of American scholars at the end of the 1960s. There is a very substantial enterprise devoted to translating Bakhtin's fragmentary works from Russian and interpreting them in terms of literary theory and epistemology. Bakhtin wrote sympathetically about the historian's imagination (e.g., the work of Marc Bloch) and opposed metahistorians like Spengler who treated societies as fixed units rather than open and constantly changing constructs. There are interesting parallels between the ideas of Bakhtin and those of political philosopher Jurgen Habermas, who has emphasized open dialogue within a public sphere as the foundation of democratic society.

${ }^{58}$ Robinson, Pacific Edge, 95; Carol Franko, "Working the 'In-Between': Kim Stanley Robinson's Utopian Fiction," Science-Fiction Studies 21 (1994): 191-211; Moylan, "Utopia is when our lives matter,"' 4,11 .

${ }^{59}$ Foote, "A Conversation with Kim Stanley Robinson," 56; Seed, "Mars Trilogy," 77. 
and the deliberate construction of civil society. As do many historians, he structures his narratives around the discords between utopian expectations and the practical compromises of an ethnically and culturally mixed society. These are the same concerns that animate Mikhail Bakhtin's criticism and make his ideas relevant, for Bakhtin's work is an effort to reinvigorate the political functions of fiction and to explore the ways in which literary texts must be understood in the context of their culture. In response to critics who suggested this connection, Robinson introduced an explicit reference to Bakhtin in Blue Mars as a way to argue that no one voice can be authoritative in a complex society.

A number of readings of Robinson's work are possible within this framework of social meaning. Science fiction critics, for example, tend to see both trilogies as reviving the critical utopias that flourished in the ferment of the 1970s, especially among writers with sympathy for that decade's feminist analysis. Ursula LeGuin, Marge Piercy, Joanna Russ, and Samuel Delany are examples of such New Wave science fiction writers whom Robinson acknowledges as influences. ${ }^{60}$ Socialist critics focus on the exposition of the "gift economy" in the Mars narrative as an alternative to capitalism. And, to be sure, the books devote substantial attention to the possibilities and problems of an economy based on the principle of sustainability, or seeking to make one's impact on natural systems neutral in the long run. ${ }^{61}$

I remain intrigued by the western history reading. The Orange County volumes are explicit efforts to think through possible contingencies of western American development. We can contrast their postmodern orientation to incremental change with Ernest Callenbach's earlier and "modern" vision of a comprehensive and enlightened acceptance of Ecotopia. ${ }^{62}$ The echoes of North America on the Martian frontier are also so pervasive that they need to be acknowledged and understood as critical commentaries on the American experience. At the same time, much of the new western history has itself been a political project, concerned to surface and legitimate alternative voices and understandings, to expand the public sphere, and to criticize the effects of unequal power.

Robinson and many new western historians have been probing the same questions-the power of capital, the imperatives of technology, the roots of community in shared action, the tensions between planetary and parochial values, the moral

${ }^{60}$ Ursula K. LeGuin, The Dispossessed: An Ambiguous Utopia (New York, 1974); Joanna Russ, The Female Man (New York, 1975); Marge Piercy, Woman on the Edge of Time (New York, 1976); Samuel R. Delany, Triton (Boston, 1976). See Jackson, "Interview with Kim Stanley Robinson," 17.

${ }^{61}$ Another use of the western experience is the settlers' concern to develop cultural strictures against potlatching, or the use of excessive gifts to obtain moral leverage over and above the needs for everyday life. See Robinson, Green Mars, 291-3.

${ }^{62}$ Ernest Callenbach, Ecotopia: The Notebooks and Reports of William Weston

(Berkeley, 1975). 
complexity of social choices, the power of past choices to constrain and direct the present. ${ }^{63}$ Martians repeatedly try to build new societies innocent of history and fail each time. The books are thick with people, surrounding the protagonists with a dense supporting cast who have their own goals and points of view, thereby mirroring the constraints on real historical actors. ${ }^{64}$ As a foundation for all of these topics, the theme of continuity is everywhere in the trilogies as each generation deals with an ever more complicated and historicized present, just as it is present in the minds of newer western historians. To swipe a turn of phrase, they come out of something in the same intellectual soil, out of the same American effort to probe the past in order to maintain a critical hope for the civic future.

${ }^{63}$ The index of Patricia Limerick's Something in the Soil (see note 40) has twenty-one subtopics listed under American West; seventeen of them, from "accumulated memories and stories of" to "tourism in," are also applicable to "Three Californias" and the Mars books.

${ }^{64}$ My thanks to Amy Bridges for this insight. 